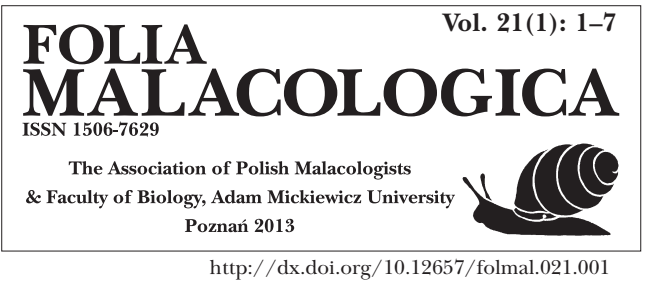

\title{
PHYLOGENETIC RELATIONSHIPS OF DALMATINELLA FLUVIATILIS RADOMAN, 1973 (CAENOGASTROPODA: RISSOOIDEA)
}

\author{
ANDRZEJ FALNiOWSKI, MAGDALENA SZAROWSKA
}

\begin{abstract}
Department of Malacology, Institute of Zoology, Jagiellonian University, Gronostajowa 9, 30-387 Cracow, Poland (e-mail: andrzej.falniowski@uj.edu.pl)

ABSTRACT: Morphology of Dalmatinella fluviatilis Radoman, 1973, a putative endemite of the Zrmanja River (Croatia), was checked. Shell, radula, and soft part anatomy were considered. In both male and female genitalia D. fluviatilis resembled Anagastina and Radomaniola. Molecular phylogeny, inferred from the mitochondrial cytochrome oxidase subunit I (COI) and nuclear 18S rRNA gene partial sequences, confirmed morphological observations: the sister taxa of Dalmatinella being Graecoarganiella, Radomaniola and Anagastina, and Dalmatinella belonging to the Sadlerianinae.
\end{abstract}

KEY WORDS: Rissooidea, molecular phylogeny, DNA, COI, 18S rRNA, morphology

\section{INTRODUCTION}

The river Zrmanja in Croatia, 69 km long, its catchment area covering $907 \mathrm{~km}^{2}$, is one of the European diversity hot spots of freshwater gastropods. It is inhabited by 16 species, five of them endemic (STRONG et al. 2008; 22 species according to BERAN 2011). Rissooidea are represented by three species found in the brackishwater part below the Jankovica Buk waterfalls, and by eight species in the freshwater part above Jankovica Buk. Three of the freshwater species: Belgrandiella zermanica Radoman, 1973, Islamia zermanica Radoman, 1973, and Lithoglyphulus tedanicus Schlickum et Schütt, 1971 [=Tanousia zrmanjae (Brusina, 1866) ] (RADOMAN 1983) are not found anywhere else. Dalmatinella fluviatilis Radoman, 1973, the only representative of Dalmatinella Radoman, 1973 described so far, can probably be considered another endemite of the Zrmanja. Apart from this river it was reported from the lowest part of the Neretva river, between Kula and Opuzen (RADOMAN 1983). We collected rissooids from that part of the Neretva twice (2001, 2004) and did not find any Dalmatinella. It seems hardly probable that the latter locality, isolated from the Zrmanja by a distance of more than $200 \mathrm{~km}$ with no record of $D$. fluviatilis, is inhabited by the same species. Passive transportation by birds (see FALNIOWSKI \& SZAROWSKA 2011a for a review), not excluded, does not explain why $D$. fluviatilis should not be found in any other river of this region. Anyway, the possibility that there are two relic populations of the species cannot be excluded.

The aim of the present paper is to check the morphology of $D$. fluviatilis from its type locality, Jankovica Buk waterfalls, and to infer its phylogenetic relationships using molecular data.

\section{MATERIAL AND METHODS}

The material was collected from Jankovica Buk waterfalls, the Zrmanja River, Croatia, $44^{\circ} 12^{\prime} 09.8^{\prime \prime} \mathrm{N}$, $15^{\circ} 43^{\prime} 16.9^{\prime \prime} \mathrm{E}, 9 \mathrm{~m}$ a.s.l., with a sieve.

The snails were fixed with $80 \%$ ethanol. The shells were cleaned in an ultrasonic cleaner and photographed with a CANON EOS 50D digital camera. 
Three adult males and three females were dissected under a NIKON SMZ-U stereomicroscope. Female genitalia (pallial oviduct) were examined using a MOTIC light microscope. Radulae were examined using a JEOL JSM-5410 scanning electron microscope, applying the techniques described by FALNIOWSKI (1990).

DNA was extracted separately from foot tissue of five specimens. The tissue was hydrated in TE buffer $(3 \times 10 \mathrm{~min}$.$) ; then total genomic DNA was extracted$ with the SHERLOCK extracting kit (A\&A Biotechnology), and the final product was dissolved in $20 \mu \mathrm{l} \mathrm{TE}$ buffer. The PCR reaction was performed with the following primers: LCO1490 (5'-GGTCAACAAATCAT AAAGATATTGG-3') (FOLMER et al. 1994) and COR722b (5'-TAAACTTCAGGGTGACCAAAA AATYA-3') (WILKE \& DAVIS 2000) for the cytochrome oxidase subunit I (COI) mitochondrial gene; SWAM18SF1 (5'-GAATGGCTCATTAAATCAGTCGA GGTTCCTTAGATGATCCAAATC-3') and SWA M18SR1 (5'-ATCCTCGTTAAAGGGTTTAAAGTGTA CTCATTCCAATTACGGAGC-3') for the nuclear 18S rRNA gene (PALUMBI 1996). The PCR conditions were as follows: COI - initial denaturation step of 4 min at $94^{\circ} \mathrm{C}$, followed by 35 cycles of $1 \min$ at $94^{\circ} \mathrm{C}, 1$ $\min$ at $55^{\circ} \mathrm{C}, 2 \mathrm{~min}$ at $72^{\circ} \mathrm{C}$, and a final extension of 4 min at $72^{\circ} \mathrm{C} ; 18 \mathrm{~S}$ - initial denaturation step of 4 min at $94^{\circ} \mathrm{C}$, followed by 40 cycles of $45 \mathrm{~s}$ at $94^{\circ} \mathrm{C}, 45 \mathrm{~s}$ at $51^{\circ} \mathrm{C}, 2 \mathrm{~min}$ at $72^{\circ} \mathrm{C}$ and, after all cycles were completed, an additional elongation step of $4 \mathrm{~min}$ at $72^{\circ} \mathrm{C}$ was performed. The total volume of each PCR reaction mixture was $50 \mu \mathrm{l}$. To check the quality of the PCR products $10 \mu \mathrm{l}$ of the PCR product was run on $1 \%$ agarose gel. The PCR products were purified using Clean-Up columns (A\&A Biotechnology) and the purified PCR products were cycle-sequenced in both directions (HILLIS et al. 1996) using BigDye Terminator v3.1 (Applied Biosystems), following the manufacturer's protocol and with the primers described above. The sequencing reaction products were purified using ExTerminator Columns (A\&A Biotechnology); DNA sequences then underwent electrophoresis on an ABI Prism sequencer. All the sequences were deposited in GenBank (Table 1).

The COI sequences were aligned by eye using BioEdit 5.0.0 (HALL 1999) and edited with

Table 1. Taxa used for phylogenetic analyses, with their GenBank Accession Numbers and references

\begin{tabular}{|c|c|c|c|}
\hline Species & 18S GB\# & COI GB\# & References \\
\hline Adriohydrobia gagatinella (Küster, 1852) & AF367657 & AF317881 & WILKE \& FALNIOWSKI (2001) \\
\hline Adrioinsulana conovula (Frauenfeld, 1863) & AF367656 & AF367628 & WILKE et al. (2001) \\
\hline Agrafia wiktori Szarowska et Falniowski, 2011 & JF906758 & JF906762 & SZAROWSKA \& FALNIOWSKI (2011) \\
\hline Alzoniella finalina Giusti et Bodon, 1984 & AF367686 & AF367650 & WILKE et al. (2001) \\
\hline Anagastina zetavalis (Radoman, 1973) & EF070622 & EF070616 & SZAROWSKA (2006) \\
\hline Bithynia tentaculata (Linnaeus, 1758) & AF367675 & AF367643 & WILKE et al. (2001) \\
\hline Boleana umbilicata (Kuščer, 1932) & JX982797 & JX982795 & FALNIOWSKI \& SZAROWSKA (2012) \\
\hline Dalmatinella fluviatilis Radoman, 1973 & KC344539 & KC344541 & present study \\
\hline Dalmatinella fluviatilis Radoman, 1973 & KC344540 & KC344542 & present study \\
\hline Daphniola graeca Radoman, 1973 & EF070624 & EF070618 & SZAROWSKA (2006) \\
\hline Dianella thiesseana (Kobelt, 1878) & AY676125 & AY676127 & SZAROWSKA et al. (2005) \\
\hline $\begin{array}{l}\text { Graecoarganiella parnassiana Falniowski } \\
\text { et Szarowska, } 2011\end{array}$ & JN202341 & JN202348 & FALNIOWSKI \& SZAROWSKA (2011b) \\
\hline Graziana alpestris (Frauenfeld, 1863) & AF367673 & AF367641 & WILKE et al. (2001) \\
\hline Grossuana codreanui (Grossu, 1946) & EF061916 & EF061919 & SZAROWSKA et al. (2007) \\
\hline Hauffenia tellinii (Pollonera, 1898) & AF367672 & AF367640 & WILKE et al. (2001) \\
\hline Hydrobia acuta (Draparnaud, 1805) & AF367680 & AF278808 & WILKE \& DAVIS (2000) \\
\hline Islamia piristoma Bodon et Cianfanelli, 2001 & AF367671 & AF367639 & WILKE et al. (2001) \\
\hline Pseudamnicola lucensis (Issel, 1866) & AF367687 & AF367651 & WILKE et al. (2001) \\
\hline Pyrgula annulata (Linnaeus, 1767) & AY676124 & AY341258 & SZAROWSKA et al. (2005) \\
\hline Radomaniola callosa (Paulucci, 1881) & AF367685 & AF367649 & WILKE et al. (2001) \\
\hline Rissoa labiosa (Montagu, 1803) & AY676126 & AY676128 & SZAROWSKA et al. (2005) \\
\hline Sadleriana fluminensis (Küster, 1853) & AF367683 & AY273996 & WILKE et al. (2001) \\
\hline Trichonia kephalovrissonia Radoman, 1973 & EF070630 & EF070619 & SZAROWSKA (2006) \\
\hline Ventrosia ventrosa (Montagu, 1803) & AF367681 & AF118335 & WILKE \& DAVIS (2000) \\
\hline
\end{tabular}


MACCLADE 4.05 (MADDISON \& MADDISON 2002). For 18S, an initial alignment was performed using CLUSTALX 1.82 (THOMPSON et al. 1997) and edited with MACCLADE. Mutational saturation for the COI dataset was examined by plotting the numbers of transitions and transversions for all the codon positions together, and for the 3rd position separately, against the percentage sequence divergence, using DAMBE 5.2 .9 (XIA 2000). We also used DAMBE 5.2.9 to perform the saturation test (XIA et al. 2003). It revealed a significant degree of saturation in the third position of the sequences. In rissooids, COI approaches saturation with about $18.6 \%$ or 120 nucleotide differences (DAVIS et al. 1998), which seems to happen after approximately 10 million years. However, to avoid a sub- stantial loss of information in the case of closely related species, this position was not excluded from the dataset and it was used for the analysis.

For Bayesian inference (BA) we used MRBAYES 3.1.2 (HUELSENBECK \& RONQUIST 2001, RONQUIST \& HuELSENBECK 2003). We selected the best model of sequence evolution for each data set using MRMODELTEST 2.2 (NYLANDER 2004), applying the Akaike Information Criterion (POSADA \& BUCKLEY 2004). The Bayesian inference was performed with the following parameters: 4 chains in two parallel analyses $(1$ cold, three heated; heating temperature $=$ 0.15) Metropolis-Coupled Monte Carlo analysis run twice in parallel for 80,000,000 generations, trees sampled every 1,000 generations starting after a

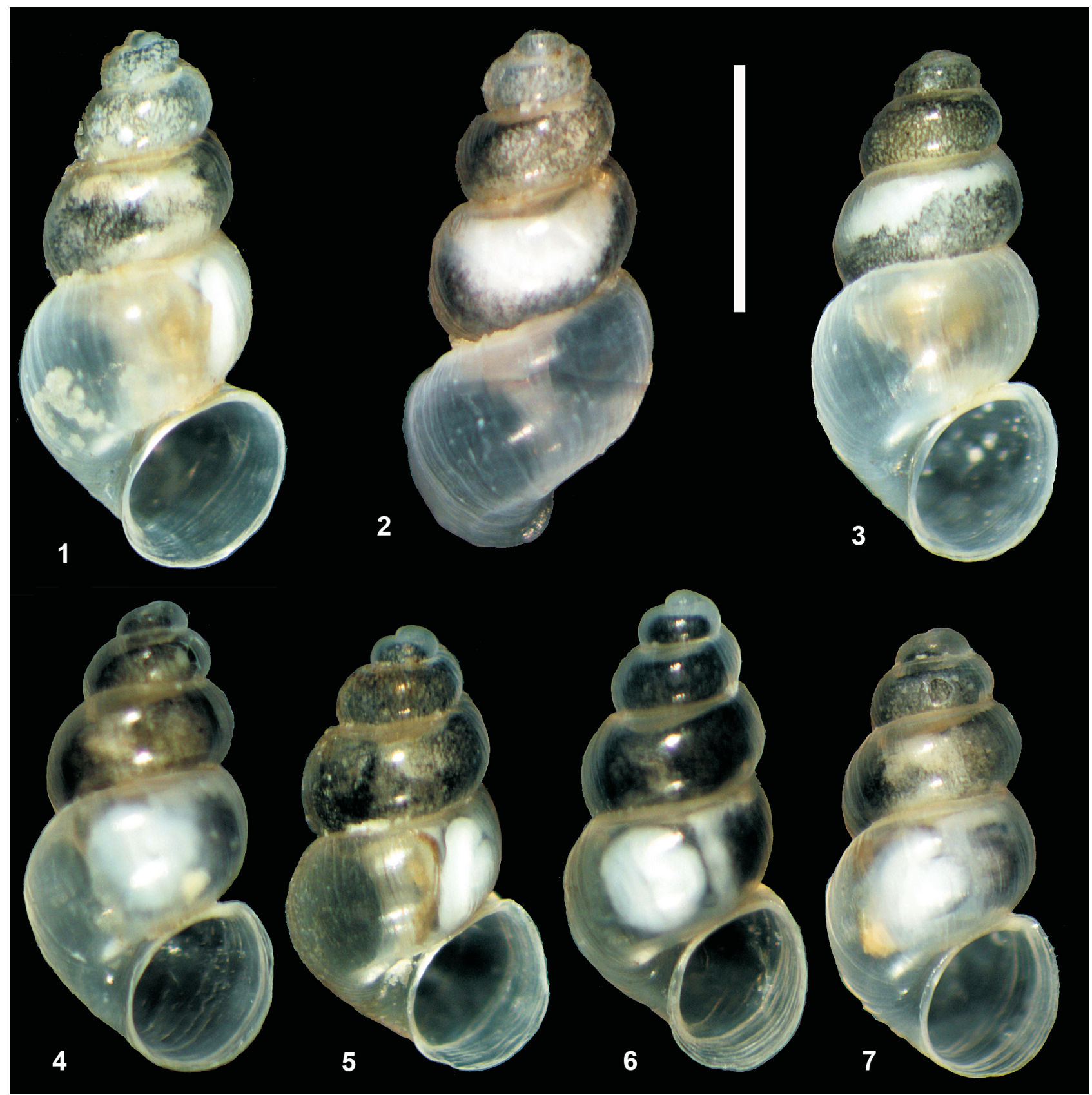

Figs 1-7. Shells of Dalmatinella fluviatilis from Jankovica Buk, bar represents $1 \mathrm{~mm}$ 
burn-in of 30,000 generations (the value chosen according to the log-likelihood values). The Bayesian inference was run unless the parallel runs achieved convergence (split frequency standard deviations $<0.001)$. The partition was set, with COI treated as coding and 18S as uncoding. We inferred majority-rule consensus tree with Bayesian (posterior) probabilities.

In the phylogeny reconstruction, we used GenBank sequences from 22 rissooid taxa (Table 1). Two of these, used as an outgroup, represented the main non-hydrobiid lineages within the Rissooidea (WILKE et al. 2001); another seven taxa represented the Hydrobiinae (including "Pyrgulinae"; SZAROWSKA et al. 2005). The remaining taxa were chosen to represent all the main lineages within the European Sadlerianinae (SZAROWSKA 2006).

\section{RESULTS AND DISCUSSION}

Shell of Dalmatinella fluviatilis (Figs 1-7) little variable, turriform; mouth rounded, ovoid, as described by RADOMAN (1973, 1974, 1983). Mantle black-pigmented (Figs 1-7); head whitish, almost lacking pigment (Figs 5-7). Ctenidium absent.
Radula (Figs 8-17) taenioglossate; central tooth formula:

$$
\frac{(4-5)-1-(4-5)}{1-1},
$$
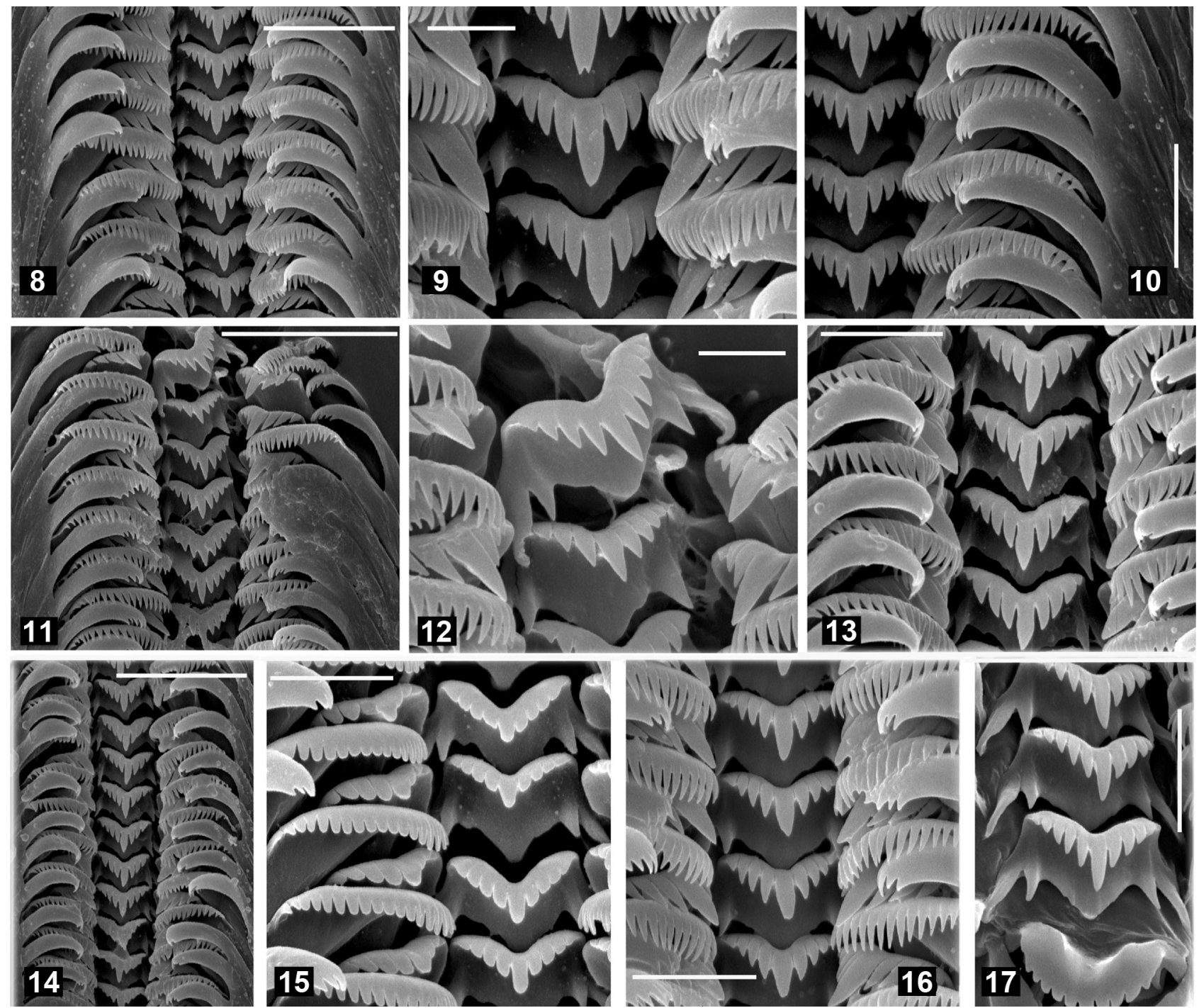

Figs 8-17. Radulae of Dalmatinella fluviatilis: 8, 11 and 14 - whole row; 9, 12 and 17 - central tooth; 10,13 and 15-16 - central, lateral and marginal teeth (bar equals: $50 \mu \mathrm{m}$ in 8, 11 and 14; $9 \mu \mathrm{m}$ in 9 and 12; $10 \mu \mathrm{m}$ in 10, 13 and 15-17) 



Figs 18-19. Penis of Dalmatinella fluviatilis

basal cusps prominent, all cusps long and sharp; lateral tooth formula: $3-1-(3-5)$, biggest cusp nearly twice as long as adjacent cusps; inner marginal tooth with 18-21 long and sharp cusps; outer marginal tooth with $6-9$ relatively massive cusps.

Penis (Figs 18-19). In its general habitus it resembles the penis illustrated by RADOMAN $(1973,1983)$, but instead of "two similar symmetrical outgrowths on the left and right side of its distal end, between whom a three-angle point is located" (RADOMAN 1983: p. 33, fig. 22), there is a double outgrowth on the left side, and the penis tip situated on the right (Figs 18-19), with the vas deferens slightly visible inside, running in zigzag (Fig. 19). Thus, the penis resembles the one typical of Anagastina Radoman, 1978 or Radomaniola Szarowska, 2006, and is quite similar to that of Graecoarganiella Falniowski et Szarowska 2011, the

Fig. 20. Renal and pallial section of female reproductive organs of Dalmatinella fluviatilis (bc - bursa copulatrix, cbc - duct of bursa copulatrix, ga - albuminoid gland, gn nidamental gland, gp - gonoporus, ov - oviduct, ovl loop of (renal) oviduct, $\mathrm{rs}_{1}$ and $\mathrm{rs}_{2}$ - receptaculum seminis, distinction after RADOMAN 1983, vc - ventral channel)

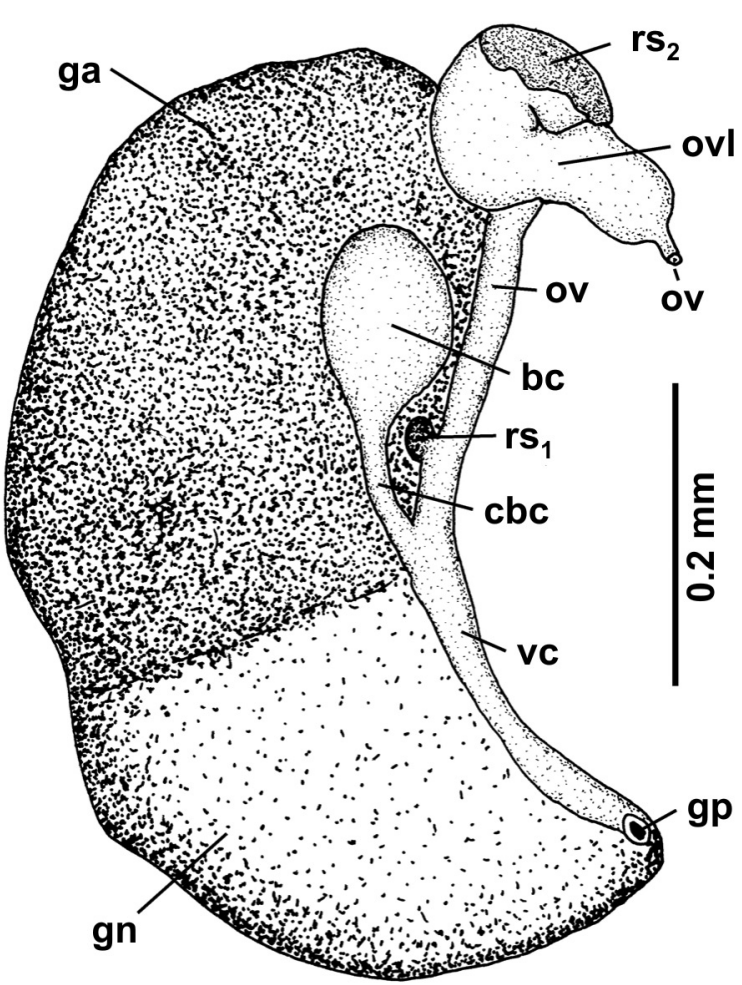






Fig. 21. Bayesian tree computed for the COI and $18 \mathrm{~S}$ sequences, Bayesian probabilities given near the relevant node if $>0.90$; asterisk indicates the clade representing Sadlerianinae

genera to which Dalmatinella is closely related in our inferred molecular phylogeny (see below).

\section{REFERENCES}

BERAN L. 2011. Non-marine molluscs (Mollusca: Gastropoda, Bivalvia) of the Zrmanja River and its tributaries (Croatia). Nat. Croat. 20: 397-409.

Davis G. M., Wilke T., SPOlskY C., QIU C.-P., QIU D.-C., XIA M.-Y., Zhang Y., RosenberG G. 1998. Cytochrome oxidase I-based phylogenetic relationships among the Pomatiopsidae, Hydrobiidae, Rissoidae and Truncatelidae (Gastropoda: Caenogastropoda: Rissoacea). Malacologia 40: 251-266.

FALNIOWSKI A. 1990. Anatomical characters and SEM structure of radula and shell in the species-level taxonomy of freshwater prosobranchs (Mollusca: Gastropoda: Prosobranchia): a comparative usefulness study. Folia Malacol. 4: 53-142.

FALNIOWSKI A., SZAROWSKA M. 2011a. Radiation and phylogeography in a spring snail Bythinella (Mollusca: Gastropoda: Rissooidea) in continental Greece. Ann. Zool. Fenn. 48: 67-90. doi: 10.5735/086.048.0201
The female reproductive organs (Fig. 20) correspond with RADOMAN's $(1973,1983)$ description: two seminal receptacles, $\mathrm{rs}_{1}$ vestigial, $\mathrm{rs}_{2}$ prominent; bursa copulatrix moderately big, pear-shaped, bursal duct short. Contrary to RADOMAN's $(1973,1983)$ figure the outlet of $\mathrm{rs}_{2}$ is far more distant from $\mathrm{rs}_{1}$.

For the COI GTR $+\mathrm{I}+\Gamma$ model was selected (with base frequencies: $\mathrm{A}=0.3563, \mathrm{C}=0.1300, \mathrm{G}=0.1166$, $\mathrm{T}=0.3971$, and substitution rate matrix: [A $\mathrm{C}]=0.4614,[\mathrm{~A}-\mathrm{G}]=8.0529,[\mathrm{~A}-\mathrm{T}]=0.0994,[\mathrm{C}-$ $\mathrm{G}]=1.4309,[\mathrm{C}-\mathrm{T}]=21.7321,[\mathrm{G}-\mathrm{T}]=1.0000$, proportion of invariable sites: $(\mathrm{I})=0.5264$, and $\Gamma$ distribution with the shape parameter $=0.4721$. For $18 \mathrm{~S}$ the SYM + $\mathrm{I}+\Gamma$ model was selected (with invariable sites and $\Gamma$ distribution, assuming the equal base frequencies, and substitution rate matrix: $[\mathrm{A}-\mathrm{C}]=1.0000,[\mathrm{~A}-$ $\mathrm{G}]=1.8443,[\mathrm{~A}-\mathrm{T}]=1.0000,[\mathrm{C}-\mathrm{G}]=1.0000,[\mathrm{C}-$ $\mathrm{T}]=4.9724,[\mathrm{G}-\mathrm{T}]=1.0000$, proportion of invariable sites: $(\mathrm{I})=0.7143$, and $\Gamma$ distribution with the shape parameter $=0.5232$.

In the Bayesian tree computed for the molecular data (Fig. 21), Anagastina, Radomaniola and Graecoarganiella, are the sister clade of Dalmatinella (Bayesian probability 0.98). This corresponds with the male and female genitalia described above. The tree (Fig. 21) shows Dalmatinella belonging to the Sadlerianinae Szarowska, 2006 (Bayesian posterior probability of the clade representing the subfamily equals 1.0 in the tree).

\section{ACKNOWLEDGEMENTS}

The study was supported by a grant from the National Science Centre (2011/01/B/NZ8/01721) to ANDRZEJ FALNIOWSKI.

FALNIOWSKI A., SZAROWSKA M. 2011b. A new genus and new species of valvatiform hydrobiid (Rissooidea; Caenogastropoda) from Greece. Moll. Res. 31: 189-199.

FALNIOWSKI A., SZAROWSKA M. 2012. Phylogenetic position of Boleana umbilicata (Kuščer, 1932) (Caenogastropoda: Rissooidea). Folia Malacol. 20: 265-270. doi: 10.2478/ v10125-012-0022-2

FOLMER O., Black M., HOEH W., LUTZ R. A., VRIJENHOEK R. C. 1994. DNA primers for amplification of mitochondrial cytochrome c oxidase subunit I from diverse metazoan invertebrates. Mol. Mar. Biol. Biotechnol. 3: 294-299.

HALL T. A. 1999. BioEdit: a user-friendly biological sequence alignment editor and analysis program for Windows 95/98/NT. Nucleic Acids Symp. Ser. 41: 95-98.

Hillis D. M., MABLE B. K., LARSON A., DAVIS S. K., ZiMMER E. A. 1996. Nucleic acids IV: sequencing and cloning. In: Hillis D. M., Moritz C., MABLE B. K. (eds). Molecular 
systematics. 2 ed. Sinauer Associates, Inc., Sunderland, Massachusetts, pp. 321-381.

HUELSENBECK J. P., RONQUIST F. 2001. MRBAYES: Bayesian inference of phylogeny. Bioinformatics 17: 754-755. doi: 10.1093/bioinformatics/17.8.754

MAdDISON D. R., MADDISON W. P. 2002. MACCLADE. Ver. 4.05. [Computer software and manual]. Sinauer Associates Inc., Sunderland.

NYLANDER J. A. A. 2004. MrModeltest Ver. 2. [Computer software and manual distributed by the author] Evolutionary Biology Centre, Uppsala University, Uppsala.

PALUMBI S. R. 1996. Nucleic acids II: the polymerase chain reaction. In: Hillis D. M., MORITZ C., MABLE B. K. (eds). Molecular systematics. 2 ed. Sinauer Associates Inc., Sunderland, pp. 205-247.

POSADA D., BUCKLEY T. R. 2004. Model selection and model averaging in phylogenetics: advantages of Akaike Information Criterion and Bayesian approaches over Likelihood Ratio Tests. Sys. Biol. 53: 793-808. doi: 10.1080/ 10635150490522304

RADOMAN P. 1973. New classification of fresh and brackish water Prosobranchia from the Balkans and Asia Minor. Posebna Izdanja, Prirodnjacki Musej u Beogradu 32: $1-30$.

RADOMAn P. 1974. Dalmatinella and Vinodolia. New fresh water genera of Prosobranchia from the Yugoslav seaside. Glasnik Prirodnjackog Museja, Beograd series B 29: 41-44.

RADOMAN P. 1983. Hydrobioidea a superfamily of Prosobranchia (Gastropoda). I. Systematics. Serbian Academy of Sciences and Arts, Monographs 547, Department of Sciences 57: 1-256.

RONQUist F., HUELSENBECK J. P. 2003. MRBAYES 3: Bayesian phylogenetic inference under mixed models. Bioinformatics 19: 1572-1574. doi: 10.1093/ bioinformatics/btg180

Strong E. E., Gargominy O., POnder W. F., Bouchet P. 2008. Global diversity of gastropods (Gastropoda; Mollusca) in freshwater. Hydrobiologia 595: 149-166. doi: 10.1007/s10750-007-9012-6

SZAROWSKA M. 2006. Molecular phylogeny, systematics and morphological character evolution in the Balkan Rissooidea (Caenogastropoda). Folia Malacol. 14: 99-168.

SZAROWSKA M., FALNIOWSKI A. 2011. An unusual, flagellumbearing hydrobiid snail (Gastropoda: Rissooidea: Hydro- biidae) from Greece, with descriptions of a new genus and a new species. J. Nat. Hist. 45: 2231-2246. doi: $10.1080 / 00222933.2011 .591067$

SZAROWSKa M., FALNiOWSKi A., Riedel F., Wilke T. 2005. Phylogenetic relationships of the subfamily Pyrgulinae (Gastropoda: Caenogastropoda: Hydrobiidae) with emphasis on the genus Dianella Gude, 1913. Zootaxa 891: $1-32$.

SZAROWSKa M., GRZMil P., FAlniowski A., SirbU I. 2007. Grossuana codreanui (Grossu, 1946) and the phylogenetic relationships of the East Balkan genus Grossuana (Radoman, 1973) (Gastropoda: Rissooidea). Hydrobiologia 579: 379-391. doi: 10.1007/s10750-006-0530-4

Thompson J. D., Gibson T. J., Plewniak F., Jeanmougin F., HigGinS D. G. 1997. The ClustalX windows interface: flexible strategies for multiple sequence alignment aided by quality analysis tools. Nucleic Acids Res. 24: 4876-4882. doi: 10.1093/nar/25.24.4876

Wilke T., DAVIS G. M. 2000. Infraspecific mitochondrial sequence diversity in Hydrobia ulvae and Hydrobia ventrosa (Hydrobiidae: Rissoacea: Gastropoda): Do their different life histories affect biogeographic patterns and gene flow? Biol. J. Linn. Soc. 70: 89-105. doi: 10.1111/j.10958312.2000.tb00202.x

Wilke T., DAVIS G. M., FALNiOWSKI A., GIUSTI F., BODON M., SZAROWSKA M. 2001. Molecular systematics of Hydrobiidae (Gastropoda: Rissooidea): testing monophyly and phylogenetic relationships. Proc. Acad. Nat. Sci. Philadelphia 151: 1-21. doi: 10.1635/0097-3157(2001)151 [0001:MSOHMG]2.0.CO;2

Wilke T., FALniowski A. 2001. The genus Adriohydrobia (Hydrobiidae: Gastropoda): polytypic species or polymorphic populations? J. Zool. Sys. Evol. Res. 39: 227-234. doi: 10.1046/j.1439-0469.2001.00171.x

XIA X. 2000. Data analysis in molecular biology and evolution. Kluwer Academic Publishers, Boston, Dordrecht \& London.

Xia X., Xie Z., Salemi M., Chen L., Wang Y. 2003. An index of substitution saturation and its application. Mol. Phyl. Evol. 26: 1-7. doi: 10.1016/S1055-7903(02)00326-3

Received: September 1st, 2012

Revised: October 7th, 2012

Accepted: October 10th, 2012 